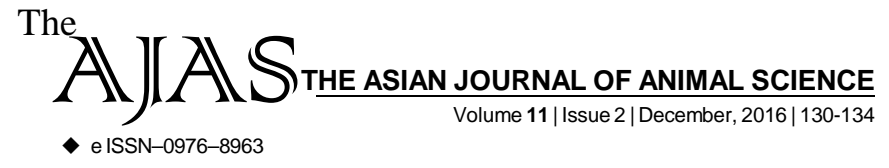

DOI : 10.15740/HAS/TAJAS/11.2/130-134 Visit us | www.researchjournal.co in

RESEARCH ARTICLE........

\title{
Technical specifications and operation of Van net of Ratnagiri, Maharashtra
}

\author{
MAYURI DONGARE, ASHISH S. MOHITE, MAKARAND SHARANGDHAR AND SHRIKANT \\ SHARANGDHAR
}

Author for Corresponding -

ASHISH S. MOHITE

Department of Fisheries

Engineering, College of Fisheries,

Shirgaon, RATNAGIRI (M.S.) INDIA

Email: ashishmohite@yahoo.com

See end of the article for

Coopted authors'

\begin{abstract}
The present study encompasses the traditional fishing method of Van net practiced in Ratnagiri, Maharashtra. Temporary barrier locally known as Van net was a very simple method employed to trap the fish and operated at a depth of 3 to $4 \mathrm{~m}$. The gear comprised of a long wall of netting supported by head rope, foot rope and wooden sticks or bamboo poles at regular intervals and operated in the area of tidal influence. PE multifilament twine having specification ranging from $210 \mathrm{D} \times 6 \times 3$ to $210 \mathrm{D} \times 12 \times 3$ and mesh size varying from 20 to $35 \mathrm{~mm}$ was commonly used for construction of main webbing. Total hung length and hung depth ranged from 200 to $355 \mathrm{~m}$ and 2 to $3.8 \mathrm{~m}$, respectively. Number of meshes in length and depth ranged from 6428 to 13000 and 70 to 190 , respectively. PP twisted rope of 1.5 to 2.5 $\mathrm{mm}$ diameter was used as head rope on upper edge and foot rope on lower edge. A total 25 to 45 wooden poles of 3.5 to $4.5 \mathrm{~m}$ height and 40 to $60 \mathrm{~mm}$ diameter were used to stretch the long wall of webbing horizontally and vertically as floats and sinkers were not used.
\end{abstract}

KEY WORDS...... Traditional fishing methods, Temporary barriers, Van net

HOW TO CITE THIS ARTICLE - Dongare, Mayuri, Mohite, Ashish S., Sharangdhar, Makarand and Sharangdhar, Shrikant (2016). Technical specifications and operation of Van net of Ratnagiri, Maharashtra. Asian J. Animal Sci., 11(2): 130-134. DOI : 10.15740/HAS/TAJAS/11.2/130-134.

ARTICLE CHRONICLE - Received : 16.06.2016; Revised : 29.10.2016; Accepted : 14.11.2016 